\title{
Kombinált gépi parodontológiai kürettálás klinikai hatékonyságának tájékozódó vizsgálata és összehasonlítása a hagyományos manuális eljárással
}

\author{
DR. KARÁCSONYI BENCE SÁNDOR*, DR. BRAUNITZER GÁBOR**, DR. ŐSZE GÁBOR, DR. PÁRKÁNYI LÁSZLÓ*
}

\begin{abstract}
Enyhe és közepes krónikus parodontális gyulladások oki kezelését többnyire sikerrel végezhetjük konzervatív módon, nem sebészi terápiával (szubgingivális kürett). A kezelés kézi eszközökkel végezve egyes páciensek számára a megfelelő anesztézia ellenére is kellemetlenségekkel járhat, illetve meglehetősen időigényes. A gépi eszközök (különösen a homokfúvó) alkalmazása viszont még nem épült be a mindennapi gyakorlatba. Célunk az volt, hogy a klinikánkon újonnan bevezetett kombinált gépi (ultrahangos és homokfúvással végzett) kürettálással kapcsolatos kezdeti klinikai tapasztalatainkat a hagyományos, kézi eszközzel végzett terápiával összevetve írjuk le. Az összehasonlításhoz a 2019 júniusától 2020 februárjáig terjedő időszakban azonos orvos által a két eljárás valamelyikével kezelt, egyéb betegségben nem szenvedő, nem dohányzó pácienseink betegkartonjait elemeztük. Klinikai paraméterek javulása tekintetében a manuális és gépi eljárás közel azonos hatékonyságot mutatott, ugyanakkor gépi technikával a kezelések hossza szignifikánsan lerövidül, a páciensek pedig a gépi kezelést jóval kevésbé érzik kellemetlennek.
\end{abstract}

Kulcsszavak: parodontitis, szubgingivális kürett, parodontitis nem sebészi terápiája

\section{Bevezetés}

A parodontitis a fogágy gyulladásos megbetegedése, melyet a fogak kemény és lágy támasztószöveteinek progresszív destrukciója jellemez, és végső soron a fogak elvesztéséhez vezet. Hazánkban a fogágy gyulladásos megbetegedései igen gyakoriak: Hermann és munkatársai 4153 főből álló reprezentatív felnőtt populációban mindössze 12\%-nak találták az egészséges fogággyal bírók arányát [8]. Lényeges kiemelni, hogy a fogágy krónikus gyulladását az irodalom számos nem fogászati kórképpel is összefüggésbe hozza [10, 22].

A parodontitis fő etiológiai tényezője a dentális biofilm patogén baktériumflórája, illetve az orális mikrobióta összetételének patogén irányba tolódása, amit újabb terminológiával disbiozisnak nevez mind a parodontális, mind a gasztroenterológiai irodalom [11]. Bár a szupragingivális fogkő magában nem primer oki tényező a destruktív fogágybetegség patomechanizmusában, de mint elsődleges plakk retenciós tényező jelentősen elősegíti a gyulladásos folyamat mélyre terjedését az egyébként arra fogékony szervezetben [1]. A subgingivalis fogkő, azonban már az egyik legfontosabb tényező a tasakban a disbiotikus állapot kialakulásában.

Ennek megfelelően az oki parodontális terápia fő célja a dentális biofilm és subgingivalis fogkő eltávolítása annak érdekében, hogy egy a szöveti regenerációnak kedvező környezetet hozhassunk létre [9]. Fontos, hogy az oki kezelés a kórfolyamat minél korábbi pontján megkezdődjön, hiszen a parodontitis elörehaladott stádiumaiban már kimondottan a szöveteket roncsoló immunfolyamatok kerülnek túlsúlyba [17], ez pedig a kielégítő regeneráció esélyeit nagyban rontja. Ilyenkor az oki terápia önmagában - bár mindenképpen szükséges többnyire már nem kielégítő, a kezelést sebészi eljárásokkal kell kiegészíteni. Jelen dolgozatunkban kizárólag az oki terápiával foglalkozunk.

A plakk- és fogkő-eltávolítás megszokott eszközei az ultrahangos depurátorok és kézi műszerek. Előbbiek magas frekvenciájú rezgés segítségével lazítják fel a biofilmet és/vagy fogkövet (jellemzően a fogíny szintjében vagy afelett, tehát szabad fogfelszínen), az utóbbiak alkalmazása során az eszközzel, annak vágó élén keresztül kézi erőt viszünk át a fogfelszínre, és mechanikai úton távolítjuk el a felszínről a biofilmet és/vagy fogkövet (a fogíny szintje alatt és felett). A szupragingivalis depurlásnak mai napig a leghatékonyabb eszköze az ultrahangos depurátor

Bár ma még a szubgingivális depurálás, az ún. nem sebészi tasakkezelésben a "gold standard", a kézi eszközökkel végzett tisztítás és kezelés kétségtelenül hatékony [5], vele szemben azonban már számos kritika megfogalmazható. Évtizedek óta ismert például az, hogy a foggyökerek kézi eszközzel történő megtisztí- 
tása a foggyökeret is károsítja, abból jelentős mennyiségű anyagot vesz el $[6,7]$. Az irodalom éppen erre tekintettel jó ideje hangsúlyozza az ultrahangos eljárás elönyeit szubgingiválisan is [2, 3,12], különösen, hogy a gépi megmunkálás hatékonysága nem marad el a kézi megmunkálásétól [20, 21]. Kiemelendő, hogy a gépi eljárás kevésbé időigényes [14, 20,23], ami a klinikus és a beteg szempontjából is egyértelmű előny. Mindezeket figyelembe véve a minimálinvazivitás követelményének a gépi eljárások látszólag jobban megfelelnek.

A legújabb gépi eljárások közé tartozik a homokfúvás, amely szupra- és szubgingiválisan is alkalmazható [13]. Nevével ellentétben az eljárás természetesen nem homokot, hanem biológiailag inert port alkalmaz, amelyet nagy nyomással juttat a fogfelszínre. Egyértelmú elönye, hogy a kezelés a felszínen található szennyezödéseket eltávolítja, ugyanakkor a fog keményszöveteinek roncsolására nem alkalmas, így kiküszöböli a kézi műszeres terápia egyik legnagyobb hátrányát. (1. kép)

Klinikánkon 2019 júniusa óta rendelkezésünkre áll egy kombinált eszköz, amellyel ultrahangos és homokfúvásos szubgingivális kezelés (kürettálás) is megvalósítható. Gépi kezelést jelenleg elsősorban ott alkalmazunk, ahol az első vizit alkalmával jelentős fogkőképződést ta- pasztalunk. Amennyiben gépi kezelést végzünk, az ultrahangos eljárást és a homokfúvást kombinálva alkalmazzuk. Vizsgálatunk célja annak retrospektív vizsgálata volt, hogy a kombinált eljárás klinikai hatékonysága az első fél évben elvégzett kezelések alapján hogyan viszonyul a hagyományos kézi múszeres megmunkálás hatékonyságához. Az elemzéshez klinikai parodontológiai paramétereket és rutinszerüen rögzített szubjektív változókat is figyelembe vettünk.

\section{Anyagok és módszerek}

A kezelések sikerességének elemzéséhez a 2019. június - 2020. február időszakban kezelt pácienseink betegkartonjait elemeztük. A kezelések viszonylag alacsony elemszáma miatt szigorú kritériumokat alkalmaztunk, hogy az egyes esetek szélsőséges eltéréseinek torzító hatását minél jobban kizárjuk. Ennek értelmében csak olyan páciensek kartonjai kerültek beválogatásra, akik enyhe vagy középsúlyos, progresszió szerint a 2018-as EFP klasszifikáció szerint stádium I, II és A osztályba sorolható [19] parodontitisben szenvednek, nemdohányzók és mentesek bármely olyan szisztémás

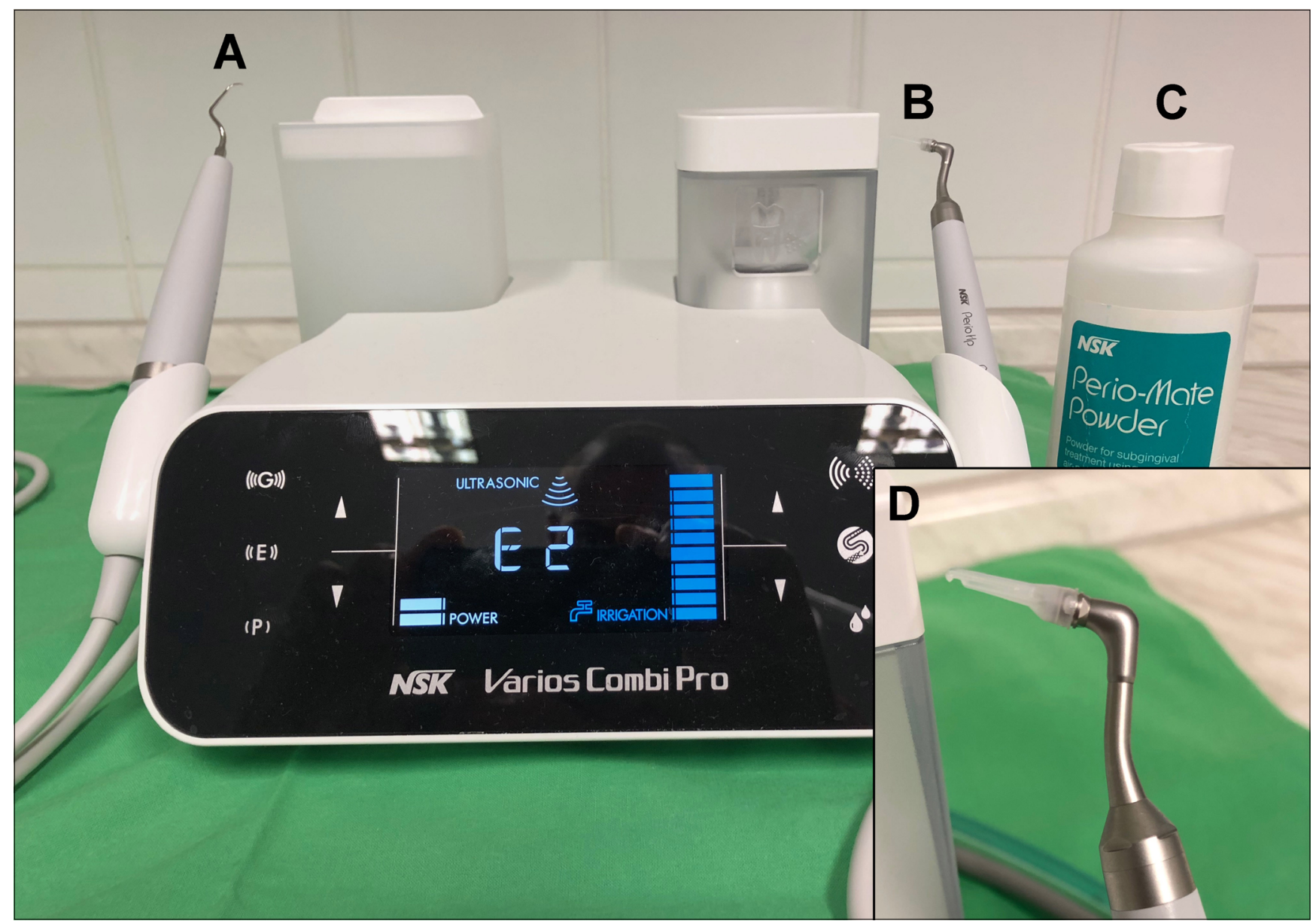

1. kép: A kezelések során alkalmazott kombinált berendezés,

az ultrahangos $(A)$ és homokfúvó $(B)$ végződésekkel, valamint a kezeléshez használatos porral $(C)$. Homokfúvás során a végződés vége felé ellaposodó kialakítású, különféle méretekben elérhető, cserélhető múanyag fejének (D) végét illesztjük a sulcusba vagy tasakba. 
megbetegedéstől, amely a fogágy állapotát, illetve gyógyhajlamát önmagában is károsan befolyásolja (pl. diabetes). Klinikai paraméterek tekintetében szempont volt, hogy a szondázási mélység az első vizsgálatkor egyetlen mérési ponton sem haladhatta meg a $6 \mathrm{~mm}$-t, azonban legalább 2 mérési ponton a szondázási mélységnek el kellett érnie az $5 \mathrm{~mm}$-t. Végül szempont volt, hogy a két csoport lehetőség szerint életkor és nem szempontjából is összehasonlítható legyen, és a betegek kezelőorvosa azonos legyen.

llyen módon a kézzel és géppel kezelt csoportba is 10-10 páciens kartonját válogattuk be. A manuálisan kezelt csoport átlagéletkora a kezelések kezdetekor $50,4 \pm 5,45$ év volt, a gépi kezelésű csoport átlagéletkora 51,0 $\pm 13,75$ évnek adódott. Mindkét csoportot szinte kizárólag női páciensek alkották, a nők aránya a kézzel kezeltek között 90\%, a géppel kezeltek között $80 \%$ volt. Az elemzés a manuális eljárással kezelt csoportban összesen 177, a gépi csoportban 155 fog kezelését érintette.

A két csoport esetén a kezelés kezdeti fázisa megegyezett. Az első ülésben teljes körű parodontális státuszfelvétel és szupragingivális gépi depurálás, polírozás, valamint instruálás és motiválás történt. A konzervatív kezelést és az egyéni szájhigiéniát negatívan befolyásoló helyi tényező́k eliminálása (sínezések, plakkretentív tényezők korrekciója) szintén ebben az ülésben történt meg.

A kezelés 1-2 héttel az első ülést követően folytatódott (második ülés), a kezelési csoportok lényegében ekkor alakultak ki. Manuális kezelés esetén a második ülésben kézi depurátorokkal és kürettekkel az összes tasakra kiterjedő szubgingivális instrumentálás, majd $0,2 \%$-os klórhexidin oldattal és fiziológiás sóoldattal a tasakok átöblítése történt. Gépi kezeléskor az eszköz (NSK Varios Combi Pro, NSK, Japán, 1. kép) parodontális nem sebészi kezelésre indikált fejeivel az összes tasakra kiterjedő szubgingivális ultrahangos instrumentálás történt, amit a készülék homokfúvójának szubgingiválisan is alkalmazható abrazív porával (Perio-Mate Powder, NSK, Japán) történő gyökérsimítás követett. Végül a tasakokat $0,2 \%$-os klórhexidin oldattal és fiziológiás sóoldattal öblítettük át. A kezelést mindkét esetben instruálás és motiválás zárta le. Az operatőr mind a manuális, mind a gépi eljárás tekintetében gyakorlott volt.

A parodontális státusz újraértékelésére (a kezelés eredményességének felmérésére) 6-8 héttel a második ülést követően került sor.

A betegkartonokból a következő adatokat nyertük ki elemzés céljából: a kezelés hossza (az érzéstelenítéstôl az instrumentálás befejezéséig, percben kifejezve), a kezelés szubjektíve megélt kellemetlensége (10 fokozatú skálán kifejezve, ahol 0 jelentése „egyáltalán nem kellemetlen”, 10 jelentése „nagyon kellemetlen”), átlagos klinikai tapadási nívó (mCAL), átlagos szondázási mélység ( $\mathrm{mPD}$ ), plakkindex $(\mathrm{PI})$ és gingivális vérzési in$\operatorname{dex}(\mathrm{GBI})$. Mindezen paramétereket páciensenként külön-külön elemeztük. Ezek közül az első kettő egyszer, közvetlenül a második kezelés után kerül rögzítésre, a továbbiak (amelyek a parodontális gyulladás és az egyéni szájhigiéné nemzetközi irodalomban elfogadott mérőszámai) az első és a harmadik üléskor. Számoltuk a klinikai tapadási nívóban (CAL) a kezelés hatására bekövetkező változást, ezt a harmadik ülés alkalmával

A parodontológiai paraméterek értelmezése és számításuk módja.

Rövidítések: (m)CAL- (átlagos) klinikai tapadási nívó; $(m) P D$ - (átlagos) szondázási mélység;

PI-plakkindex; GBI-gingivális vérzési index; mCAL-G: átlagos tapadásnyereség

\begin{tabular}{|c|c|c|}
\hline Paraméter & Definíció & Számítás módja \\
\hline$P D / m P D$ & $\begin{array}{l}\text { A marginális gingiva és a sulcus/tasak bázisa közötti távolság. } \\
\text { Teljes fogazatra vonatkozó átlagértéke az mPD. }\end{array}$ & $\begin{array}{l}\text { Parodontális szondát mérsékelt erővel } \\
\text { a tasak bázisáig levezetve a marginális gingiva } \\
\text { szintjében a szondáról leolvasható érték. }\end{array}$ \\
\hline$C A L / m C A L$ & $\begin{array}{l}\text { A zománc-cement határtól a sulcus (kóros esetben: tasak) } \\
\text { bázisáig mért távolság, milliméterben megadva. } \\
\text { A nagyobb értékek jelentősebb tapadásvesztést, } \\
\text { súlyosabb kórfolyamatot jeleznek. } \\
\text { Teljes fogazatra vonatkozó átlagértéke az mCAL. }\end{array}$ & $\begin{array}{l}\text { Normál helyzetű (a zománc-cement } \\
\text { határ szintjében elhelyezkedő) marginális gingiva } \\
\text { esetén CAL = PD. Ennél koronálisabb } \\
\text { vagy apikálisabb elhelyezkedésű marginális gingiva } \\
\text { esetén a PD-t az eltéréssel korrigálni kell, } \\
\text { hogy mindig a zománc-cement határhoz } \\
\text { viszonyított értéket kapjunk. }\end{array}$ \\
\hline \multirow[b]{2}{*}{$P I$} & \multirow{2}{*}{$\begin{array}{l}\text { A páciens egyéni szájhigiénéjét jellemző arányszám } \\
\text { százalékban kifejezve. Foganként } 4 \text { felszínen vizsgáljuk. } \\
\text { A teljes fogazatra adjuk meg. }\end{array}$} & plakkal borított felszínek száma \\
\hline & & összes vizsgált felszín száma $\times 100$ \\
\hline \multirow{2}{*}{$G B I$} & \multirow{2}{*}{$\begin{array}{l}\text { A parodontális gyulladás mértékét kifejező arányszám } \\
\text { százalékban kifejezve. Foganként } 6 \text { helyen vizsgáljuk, } \\
\text { szondázás hatására fellép-e vérzés. A teljes fogazatra adjuk meg. }\end{array}$} & vérző helyek száma \\
\hline & & $\overline{\text { összes vizsgált hely száma }} \times 100$ \\
\hline$m C A L-G$ & $\begin{array}{l}\text { Az újraértékelés során (a záróüléskor) } \\
\text { és a kezelés előtt rögzített mCAL értékek közti különbség. } \\
\text { A kezelés hatékonyságát a detektálható } \\
\text { tapadásnyereségen keresztül jellemzi. }\end{array}$ & mCAL-G = újraértékeléskori mCAL - kiindulási mCAL \\
\hline
\end{tabular}


rögzítettük. A parodontológiai paraméterek értelmezését az 1. táblázatban és a 2. képen adjuk meg.

A rögzített paraméterek leíró jellemzésén túl hipotézisteszteket is végeztünk. A kis elemszámra tekintettel nem-paraméteres eljárásokat választottunk: a csoporton belüli, időben eltérő mérések eredményeit a Wilcoxon-próbával hasonlítottuk össze, míg az egyes paraméterekben azonos idópontban mutatkozó, csoportok közötti eltérések vizsgálatához a Mann-Whitney-tesztet alkalmaztuk. A szignifikanciaszint minden esetben $p=0,05$ volt.

A vizsgálatot a Szegedi Tudományegyetem SzentGyörgyi Albert Klinikai Központ Regionális Humán Orvosbiológiai Tudományos és Kutatásetikai Bizottsága 2020. január 7-én 227/2019-SZTE számon engedélyezte.

\section{Eredmények}

\section{Terápiás hatékonyság}

a klinikai paraméterek tükrében

A klinikai paramétereket leíró módon a 2. táblázat foglalja össze. A szöveges leírásban kerüljük a táblázat tartalmának megismétlését, ehelyett az egyes paraméterek változásainak tendenciáira, az esetleges szignifikáns eltérésekre vagy ezek hiányára koncentrálunk. Ahogyan az a 2. táblázatból kitúnik, a vizsgált paraméterek kiinduláskori értékei a két csoportban nagy fokú hasonlóságot (esetenként egyezést) mutattak. Ennek megfelelően a csoportok között szignifikáns eltérést egyik paraméter esetében sem igazoltunk.

Manuális kezelés esetén mCAL értéke a kiindulási állapot $82 \%$-ára mérséklődött, gépi kezeléssel $84,5 \%$ ára, ami $0,63( \pm 0,4) \mathrm{mm}$ és $0,54( \pm 0,3) \mathrm{mm}$ tapadásnyereségnek feleltethető meg. Az átlagos szondázási mélység ( $\mathrm{MPD}$ ) manuális kezelés esetében átlagosan $0,62( \pm 0,4) \mathrm{mm}$ csökkenéssel a kiindulási érték $80,25 \%$-ára mérséklődött, míg gépi kezelés esetén ez a paraméter $0,58( \pm 0,3) \mathrm{mm}$ átlagos változás mellett a kiindulási érték $81,25 \%$-ára esett vissza. Ami a GBI változásait illeti, ez a paraméter manuális kezeléssel átlagosan $29( \pm 0,1) \%$-kal redukálódott a kiindulási ér- ték 26\%-ára, míg gépi kezeléssel átlag $30( \pm 0,2) \%$-nyi mérséklődés a vérzési indexet a kiindulási érték $36,27 \%$ ára szorította vissza. Mindeközben PI a kézi múszerrel kezelt csoportban átlagosan $36( \pm 0,2) \%$-kal redukálódott, a kiindulási érték 38\%-ára, a gépi csoport esetében átlag $30( \pm 0,2) \%$ csökkenés a kiindulási érték

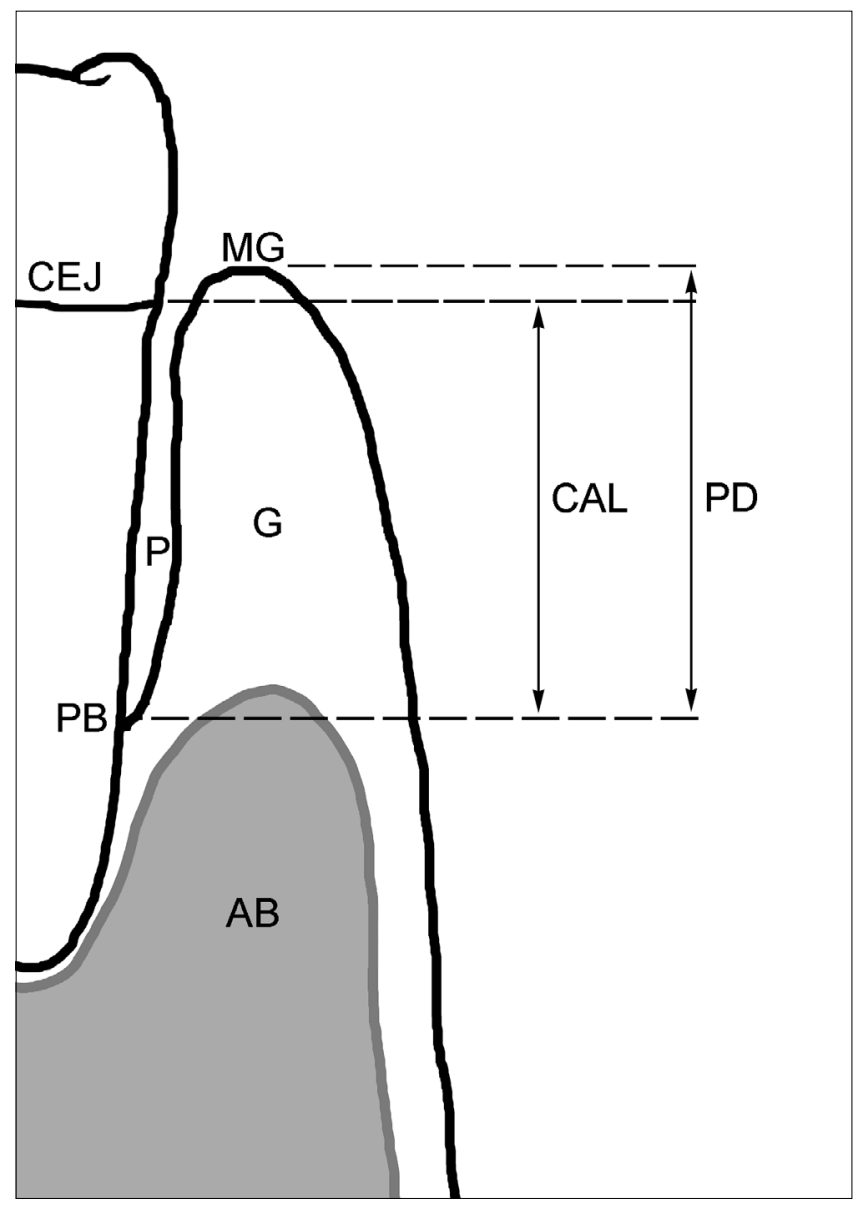

2. kép: A fog és a környező szövetek viszonyai parodontitisben, a zománc-cement határnál kissé koronálisabb elhelyezkedésű marginalis gingiva esetén (A szerzők saját ábrája.): CEJ: zománc-cement határ; $M G$ : marginális gingiva; $P$ : parodontalis tasak; G: gingiva;

$P B$ : a parodontalis tasak bázisa; $A B$ : alveolaris csont; $C A L$ : klinikai tapadásveszés; $P D$ : szondázási mélység.

A klinikai paraméterek alakulása az első és a harmadik ülés alkalmával. Az értékeket átlag ( \pm standard deviáció) formában adtuk meg.

(A paraméterekhez ld. az 1. táblázatot.)

A p-értékek a Wilcoxon-próbával kerültek meghatározásra. A különbség szignifikáns, ha $p<0,05$.

\begin{tabular}{|c|c|c|c|c|c|c|}
\hline & \multicolumn{3}{|c|}{$K E ́ Z I(N=10)$} & \multicolumn{3}{|c|}{$G E ́ P I(N=10)$} \\
\hline & 1. ülés & 3. ülés & $p$ & 1. ülés & 3. ülés & $p$ \\
\hline mCAL (mm) & $3,50 \quad( \pm 0,6)$ & $2,87 \quad( \pm 0,4)$ & $<0,01$ & $3,48 \quad( \pm 0,9)$ & $2,94 \quad( \pm 0,9)$ & $<0,01$ \\
\hline $\mathrm{mPD}(\mathrm{mm})$ & $3,24 \quad( \pm 0,4)$ & $2,60 \quad( \pm 0,3)$ & $<0,01$ & $3,20 \quad( \pm 0,4)$ & $2,60 \quad( \pm 0,2)$ & $<0,01$ \\
\hline $\mathrm{PI}(\%)$ & $57,60 \quad( \pm 9,4)$ & $22,10( \pm 21,3)$ & $<0,01$ & $63,10( \pm 19,1)$ & $33,00( \pm 18,8)$ & $<0,01$ \\
\hline GBI (\%) & $39,00( \pm 12,3)$ & $10,10 \quad( \pm 6,1)$ & $<0,01$ & $46,60( \pm 18,3)$ & $16,90( \pm 10,9)$ & $<0,01$ \\
\hline $\mathrm{mCAL}-\mathrm{G}(\mathrm{mm})$ & - & $0,63 \quad( \pm 0,4)$ & N/A & - & $0,54 \quad( \pm 0,3)$ & $\mathrm{N} / \mathrm{A}$ \\
\hline
\end{tabular}


$52 \%$-ára történő visszaesést eredményezett. A változás minden paraméter esetében és mindkét csoportban $\mathrm{p}<0,01$ szinten szignifikáns volt, ugyanakkor a végső ellenőrzéskori értékek között nem találtunk szignifikáns eltérést a két kezelési csoport között. Lényeges kiemelni, hogy a plakkindex változásának mértéke sem tért el szignifikánsan a két csoport között, tehát a páciensek szájhigiénéjének eltérései nem lehettek számottevő torzító hatással az eredményekre.

Kezelési idő, szubjektív kezelési élmény a beteg szemszögéböl

Manuális kezelés esetén a kezelési idő 45 és 80 perc között változott $(62,5 \pm 11,6$ perc átlaggal), gépi kezelés esetén egy kezelés ideje 20 és 50 perc közé esett (40,5 \pm 9,6 perc átlaggal). A két csoport közötti eltérés szignifikánsnak bizonyult $(p<0,05)$. A kezelés kellemetlenségére vonatkozó értékeléseket kizárólag leíró jelleggel elemeztük. Manuális kezelés esetén a páciensek $70 \%$-a (7 fő) a skála 1 . és 8 . fokozata közé tette a kezelés során megélt kellemetlenségét, és mindössze $30 \%$ (3 fő) jellemezte úgy a kezelést, mint ami egyáltalán nem kellemetlen (0. fokozat). Ezzel szemben a gépi kezelés legrosszabb értékelése a 3 . fokozat volt, a csoport $80 \%-a$ (8 fő) jellemezte a kezelést úgy, mint ami egyáltalán nem kellemetlen. Összefoglalva az mondható el, hogy a gépi kezelés szignifikánsan rövidebb időt vett igénybe, ugyanakkor a páciensek számára jóval kevésbé volt kellemetlen.

\section{Megbeszélés}

A klinikai paraméterek javulása tekintetében eredményeink megfeleltethetők az irodalmi adatoknak, bár az utánkövetés rövid tartama és a közlemények módszertani sokfélesége a minden szempontból összehasonlítható vizsgálatok körét meglehetősen leszűkíti. Itt kell megjegyezni, hogy hosszabb utánkövetés mellett Badersten és munkatársai [2] arra jutottak, hogy a javulás jelentős része a kezelést követő 4-5 hónapban megy végbe; ezen belül tapadásnyereség, szondázási mélység és vérzési index tekintetében szignifikáns változásokat írtak le már az első 2 hónapban is. A rövid utánkövetési idő tehát nem abszolút akadálya az öszszehasonlításnak. Boretti és munkatársai [4] 1 hónapos utánkövetéssel vetették össze a kézi müszeres és az ultrahangos eljárás hatékonyságát, nagyrészt az általunk is alkalmazott paraméterek szerint, és hozzánk hasonlóan arra jutottak, hogy a manuális és gépi eljárás klinikai eredményessége között nincs szignifikáns különbség. Eredményeik szerint a tapadásveszteség mértéke manuális eljárás esetén $76 \%$-ra, gépi kezelés esetén $87 \%$-ra mérséklődött, a szondázási mélység mindkét eljárás esetén $67 \%$-ra csökkent, míg a vérzési index manuális kezeléssel 74\%-ra redukálódott, gépi kezeléssel pedig 78\%-ra. Utóbbival kapcsolatban meg kell jegyezni, hogy ez az irodalomban is alacsony ha- tékonyságnak számít: Oosterwaal és munkatársai [18] 49 nap utánkövetési idővel azt találták, hogy a vérzési index manuális eljárással a kiindulási érték 29\%-ára, ultrahangos eljárással 22\%-ára redukálódott. Ezek az értékek saját tapasztalatunknak is jobban megfelelnek. A különbség oka vélhetően az, hogy a Boretti-féle vizsgálatba bevont páciensek vérzési indexe már a kiinduláskor is szokatlanul kedvező volt, tehát látványos javulás ebben a paraméterben nem is volt remélhető. Végül Kocher és munkatársai [12] szintén a manuális és ultrahangos eljárásokat hasonlították össze, a saját vizsgálatunk eredményeihez hasonló eredménnyel: a manuális eljárás pácienseiáknél átlagosan 0,33 $( \pm 1,16) \mathrm{mm}$ tapadásnyereséget eredményezett, géppel $0,71( \pm 1,07) \mathrm{mm}$ nyereséget sikerült elérniük. A szondázási mélységet a manuális eljárás átlagosan 0,77 $( \pm 0,8) \mathrm{mm}$-rel csökkentette, a gépi eljárással 1,10 $( \pm 0,7) \mathrm{mm}$ csökkenés volt elérhető. A vérzési index manuális eljárással a kiindulási érték $56,9 \%$-ára, gépi eljárással 42,7\%-ra volt mérsékelhető.

Általában elmondható, hogy az irodalom egységes abban, hogy mind a manuális, mind a gépi eljárások alkalmasak arra, hogy a klinikai paraméterekben szignifikáns javulást idézzenek elő, és abban is, hogy ezen módszerek klinikai hatékonysága között szignifikáns különbség nincs, annak ellenére, hogy a tanulmányok esetenként a manuális, máskor a gépi eljárás relatív előnyét jelzik. Ebbe a tendenciába saját tanulmányunk is illeszkedik. Rá kell mutatni arra is, hogy amikor az irodalom gépi kürettálást említ, az alatt kivétel nélkül ultrahangos beavatkozást ért. Az önállóan alkalmazott vagy ultrahangos eljárással kombinált homokfúvás hatékonyságáról ebben a tekintetben tanulmányunk megírásának idején megbízható adat még nem állt rendelkezésre. Ez kétségtelenül az eljárás újdonságának tudható be.

A gépi eljárás időtakarékosabb mivolta nem új eredmény, erre az irodalom alapján számítani lehetett [14, 20, 23], ugyanakkor ígéretes, hogy ez az előny még úgy is fennmaradt, hogy gyakorlatilag két gépi eljárás kombinációját alkalmaztuk.

A szubjektív betegelégedettségre, illetve kezelési élményre nézve az irodalomban nem találni adatot, ennek oka valószínűleg az, hogy szubgingivális indikációban a gépi eljárás - különösen a homokfúvás - még nem elterjedt. A rendelkezésre álló (meglehetősen szükös) irodalom elsősorban a pácienseknek a szupragingivális ultrahangos kezelések szubjektív megítélését értékelte $[15,16]$. Saját eredményeink ebből a szempontból egyértelműen a gépi eljárás előnyét jelzik, de ez a kérdés mindenképpen további vizsgálatot igényel.

Végül szubjektív orvosi tapasztalatként említjük meg, hogy a gépi eszközök használata során a taktilis viszszajelzés jelentősen romlik, így előrehaladottabb parodontitis esetén bonyolult anatómiájú, nehezen hozzáférhető területek tisztaságának ellenőrzése nehézkes lehet.

Vizsgálatunk arra enged következtetni, hogy a klinikai paraméterek felöl közelítve a manuális és a kombinált gépi kürettálás egyaránt igen hatékony, nagyjából 
azonos hatékonyságú eljárások. Abban azonban a két eljárás eltér, hogy a gépi eljárás (még kombinált jelleggel is) szignifikánsan gyorsabb, a páciensek pedig egyértelműen kedvezőbben értékelik. Mindezek alapján úgy gondoljuk, a kombinált vagy akár egyféle gépi eszközzel végzett kezelés az enyhe-középsúlyos parodontitis nem sebészi terápiájában a konvencionális kézi múszeres kezelés jó alternatívája lehet.

Anyagi támogatás: A kutatómunka anyagi támogatásban nem részesült

\section{Irodalom}

1. AKCALI A, LANG NP: Dental calculus: the calcified biofilm and its role in disease development. Periodontol 2000 2018; 76: 109-115. https://doi.org/10.1111/prd.12151

2. Badersten A, Nilveus R, Egelberg J: Effect of nonsurgical periodontal therapy. I. Moderately advanced periodontitis. J Clin Periodontol 1981; 8: 57-72. https://doi.org/10.1111/j.1600-051X.1981.tb02024.x

3. Badersten A, Nilveus R, Egelberg J: Effect of nonsurgical periodontal therapy. II. Severely advanced periodontitis. J Clin Periodontol 1984; 11: 63-76.

https://doi.org/10.1111/j.1600-051X.1984.tb01309.x

4. Boretti G, Zappa U, Graf H, et al: Short-term effects of phase I therapy on crevicular cell populations.

J Periodontol 1995; 66: 235-240.

https://doi.org/10.1902/jop.1995.66.3.235

5. Совв CM: Clinical significance of non-surgical periodontal therapy: an evidence-based perspective of scaling and root planing. J Clin Periodontol 2002; 29 Suppl 2: 6-16. https://doi.org/10.1034/j.1600-051X.29.s2.4.x

6. EwEN SJ, GwinnetT AJ: A scanning electron microscopic study of teeth following periodontal instrumentation.

J Periodontol 1977; 48: 92-97. https://doi.org/10.1902/jop.1977.48.2.92

7. Garnick JJ, DeNt J: A scanning electron micrographical study of root surfaces and subgingival bacteria after hand and ultrasonic instrumentation. J Periodontol 1989; 60: 441-447. https://doi.org/10.1902/jop.1989.60.8.441

8. Hermann P, Gera I, Borbely J, et al: Periodontal health of an adult population in Hungary: findings of a national survey. $J$ Clin Periodontol 2009; 36: 449-457. https://doi.org/10.1111/j.1600-051X.2009.01395.x

9. Jepsen S, Deschner J, Braun A, et al: Calculus removal and the prevention of its formation. Periodontol 20002011 ; 55: 167-188. https://doi.org/10.1111/j.1600-0757.2010.00382.x
10. KIM J, AmAR S: Periodontal disease and systemic conditions: a bidirectional relationship. Odontology 2006; 94: 10-21. https://doi.org/10.1007/s10266-006-0060-6

11. Kinane DF, Stathopoulou PG, Papapanou PN: Periodontal diseases. Nat Rev Dis Primers 2017; 3: 17038 https://doi.org/10.1038/nrdp.2017.38

12. Kocher T, Konig J, Hansen $P$, et al: Subgingival polishing compared to scaling with steel curettes: a clinical pilot study. J Clin Periodontol 2001; 28: 194-199. https://doi.org/10.1034/j.1600-051x.2001.028002194.x

13. Kruse AB, Maamar R, Akakpo DL, et al: Effects of subgingival air-polishing with trehalose powder on oral biofilm during periodontal maintenance therapy: a randomized-controlled pilot study. BMC Oral Health 2020; 20: 123. https://doi.org/10.1186/s12903-020-01111-9

14. Laurell L, PetTersson B: Periodontal healing after treatment with either the Titan-S sonic scaler or hand instruments. Swed Dent J 1988; 12: 187-192.

15. MuHNEY KA, DeCHow PC: Patients' perception of pain during ultrasonic debridement: a comparison between piezoelectric and magnetostrictive scalers. J Dent Hyg 2010; 84: 185-189.

16. Muller $S$, Huber $H$, Goebel $G$, et al: Pain perception during debridement of hypersensitive teeth elicited by two ultrasonic scalers. Clin Oral Investig 2017; 21: 1559-1564. https://doi.org/10.1007/s00784-016-1971-4

17. OhlRich EJ, Cullinan MP, SeYmour GJ: The immunopathogenesis of periodontal disease. Aust Dent J 2009; 54 Suppl 1: S2-10. https://doi.org/10.1111/j.1834-7819.2009.01139.x

18. Oosterwaal PJ, Matee MI, Mikx FH, et al: The effect of subgingival debridement with hand and ultrasonic instruments on the subgingival microflora. J Clin Periodontol 1987; 14: 528-533. https://doi.org/10.1111/j.1600-051X.1987.tb00995.x

19. Tonetti MS, Greenwell $H$, Kornman KS: Staging and grading of periodontitis: Framework and proposal of a new classification and case definition. J Periodontol 2018; 89 Suppl 1: S159-S72. https://doi.org/10.1002/JPER.18-0006

20. TunKel J, HeIneCKe A, FLemmig TF: A systematic review of efficacy of machine-driven and manual subgingival debridement in the treatment of chronic periodontitis.

J Clin Periodontol 2002; 29 Suppl 3: 72-81; discussion 90-91. https://doi.org/10.1034/j.1600-051X.29.s3.4.x

21. WaLmsLey AD, LeA SC, LANDINI G, et al: Advances in power driven pocket/root instrumentation. J Clin Periodontol 2008; 35: 22-28. https://doi.org/10.1111/j.1600-051X.2008.01258.x

22. WINNING L, LINDEN GJ: Periodontitis and Systemic Disease: Association or Causality? Curr Oral Health Rep 2017; 4: 1-7. https://doi.org/10.1007/s40496-017-0121-7

23. Yukna RA, Scott JB, Aichelmann-Reidy ME, et al: Clinical evaluation of the speed and effectiveness of subgingival calculus removal on single-rooted teeth with diamond-coated ultrasonic tips. J Periodontol 1997; 68: 436-442. https://doi.org/10.1902/jop.1997.68.5.436 
Karácsonyı BS, Braunitzer G, Ősze G, PÁrkányı L

\section{An exploratory study of the clinical efficiency of combined, machine-driven periodontal curettage and comparison with the conventional manual method}

Mild to moderate cases of periodontitis are usually efficiently treated in a nonsurgical way (i.e. subgingival curettage). The conventional approach uses hand instruments, which, however, is time-consuming and some patients may find it extremely uncomfortable, even in spite of anesthesia. Machine-driven curettage (especially sand-blasting) is not yet part of the everyday routine. Our aim was to share our initial experience with a new, combined, machine-driven approach to subgingival curettage that we have lately introduced in our practice, in comparison with the conventional method. The new approach combines ultrasonic debridement and sand-blasting. We retrospectively analyzed the patients' files who had undergone curettage with either method in the period June, 2019 to February, 2020. Only non-smoking patients with mild to moderate periodontitis treated by the same periodontist and free of any systemic disease were eligible. Clinical attachment level, mean pocket depth, plaque index, gingival bleeding index, treatment duration and patient satisfaction were analyzed. Regarding their efficiency in reducing the indicators of inflammation, the two methods proved to be comparable: both caused significant reduction in almost all indicators. However, treatment duration was significantly shorter with the machine-driven approach, and patients reported markedly less discomfort in connection with this approach. Within the limitations of our study, we conclude that machine-driven subgingival curettage (combined or not) may be a good alternative to the conventional manual approach in mild to moderate periodontitis, especially because it is more time-efficient, less invasive and more comfortable to the patients.

Keywords: periodontitis, subgingival curettage, periodontal instrumentation 